\title{
Biodegradation of Industrial Oil-Polluted Wastewater in Egypt by Bacterial Consortium Immobilized in Different Types of Carriers
}

\author{
Aliaa M. El-Borai ${ }^{1 *}$, Khaled M. Eltayeb ${ }^{2}$, Alaa R. Mostafa ${ }^{2}$, Samy A. El-Assar ${ }^{1}$ \\ ${ }^{1}$ Botany and Microbiology Department, Faculty of Science, Alexandria University, Egypt \\ ${ }^{2}$ Environmental Sciences Department, Faculty of Science, Alexandria University, Egypt
}

Received: 20 February 2016

Accepted: 21 March 2016

\begin{abstract}
Microbial degradation of petroleum hydrocarbons is one of the major practices in the natural decontamination process. We tested the effectiveness of some carriers and immobilization methodology for four cultures of hydrocarbon-degrading strains isolated from oil-polluted wastewater of the American Petroleum Institute (API) separators (1, 2, and 4) of the Alexandria Petroleum Company (APC), Alexandria, Egypt. Adsorbing cells on a sponge gave optimal total petroleum hydrocarbon removal efficiency for the four cultures in comparison to free cells. Comparing a designed bacterial consortium with individual cultures revealed that the highest crude oil degradation percentage was recorded by mixed culture $(81.70 \%$ removal efficiency) 1.083 times higher than that obtained from Bacillus brevis ( $75.42 \%)$. The use of a fixedbed bioreactor for biodegradation of crude oil by bacterial cultures held on sponge cubes showed that the highest crude oil degradation percentage was recorded by mixed culture $(87.53 \%)$, followed by individual cultures of Pseudomonas aeruginosa KH6 (82.97\%), providing insight for biodegradation by immobilized bacterial consortia within bioreactors. Significant degradation in both aliphatic and aromatic hydrocarbons, analyzed by GC/MS, was obtained from mixed culture adsorbed on sponge. Simulation strategy was applied for oily wastewater sample, recommending the combination of biostimulation and bioaugmentation techniques, which achieved $92.17 \%$ and $91.30 \%$ removal efficiencies in a bioreactor packed with sponge or polyethylene, respectively. Therefore, the tested strains could be utilized for industrial effluent treatment and decontamination of natural polluted areas and could be reported in future correspondence.
\end{abstract}

Keywords: crude oil degradation, immobilization, consortium, bioreactors, simulation

\section{Introduction}

Crude oil is the original mixture of a variety of petroleum hydrocarbons. The hydrocarbons in crude oil are mostly

*e-mail: aliaa_elborai2007@yahoo.com alkanes, cycloalkanes, and various aromatic hydrocarbons, while the other organic compounds contain nitrogen, oxygen, and sulfur, plus trace amounts of metals such as iron, nickel, copper, and vanadium. Polycyclic aromatic hydrocarbons (PAH) - especially the high molecular weight ones (HMWPAH) - are the most dangerous due to their xenobiotic and carcinogenic nature [1]. 
The fate of petroleum in seawater largely depends on mechanical (wave, wind), physical (temperature, UV), and chemical ( $\mathrm{pH}$, dissolved oxygen, and nutrient concentration) factors that may differently influence its natural transformation (oil weathering) and biodegradation [2]. At an early stage light fractions of oil are naturally removed - mostly by evaporation, thence by photo-oxidation and by geo-chemical reactions. Heavy fractions are instead dispersed or dissolved and only a small portion may be removed by the process of biodegradation. Although chemical-physical phenomena play an important role in the process of oil detoxification, the ultimate and complete degradation is mainly accomplished by marine microflora, the dominant bacteria in this role [3].

Man-made bioremediation technologies are intended to improve the effectiveness of natural biodegradation [4]. Two basic types of bioremediation were extensively used. Classification was either per processes (bioaugmentation and biostimulation) or they were divided into two different techniques on operational methods such as in situ and ex situ [5].

The success of oil spill bioremediation depends on the availability of the appropriate microorganisms, multiple environmental factors, and composition of the oil spilled [6]. Mixed microbial communities have the most powerful biodegradation potential because the genetic information of more than one organism is necessary to degrade the complex mixtures of organic compounds present in contaminated areas [7]. Although most organisms have detoxifying abilities (that is, mineralization, transformation, and or immobilization of pollutants), microorganisms - particularly bacteria - play a crucial role in biogeochemical cycles for sustainable development of the biosphere. Horizontal gene transfer, high growth rates, and metabolic versatility make them evolve quickly and adapt to changing environmental conditions, even in extreme environments that do not permit the proliferation of other living organisms [8].

The immobilization of hydrocarbon degraders may solve the problem of the dilution of microorganisms in open waters. In comparison with free cells, the use of immobilized cells has several advantages:

- A high population density can be achieved in a limited volume.

- It limits substrate inhibition and toxicity to microorganisms by diffusional constrains.

- It affords cellular protection against adverse environmental conditions.

- It is a reusable application, which reduces overall costs and facilitates cell storage over long periods with no loss of their degrading capacities.

Several materials such as K-carrageenan, alginate, agar, polyacrylamide hydrazide, and polyurethane foam have been used successfully for the immobilization of microorganisms [9]. Several studies have used free suspension and immobilized cultures for oil biodegradation, and the results revealed a significant increase in hydrocarbon removal efficiency within immobilized cultures [10-11]. The use of bioreactors has emerged as an interesting alternative.

Among the main advantages is the possibility of continuous monitoring of system performance, the control of optimal processing conditions (which is essential for maintaining microbial activity), and reducing remediation time [12].

This document addresses only petroleum refining. Petroleum refinery effluents are wastes originating from industries primarily engaged in refining crude oil and manufacturing fuels, lubricants and petrochemical intermediates. These effluents are a major source of aquatic environmental pollution. The aim of this study is to test the ability of immobilized individual and mixed cultures in crude oil degradation, and exploiting this ability in conducting simulation experiments in batch bioreactors for oily wastewater treatment.

\section{Experimental Procedures}

\section{Bacteria and Cultivation}

We cultivated subcultures of four strains of hydrocarbon-degrading strains isolated from oil-polluted wastewater of American Petroleum Institute (API) separators (1, 2, and 4) of the Alexandria Petroleum Company (APC), Alexandria, Egypt, in $4 \mathrm{ml}$ nutrient broth medium at $35^{\circ} \mathrm{C}$ for activation of the organisms for crude oil biodegradation. Different strains - either individual or mixed bacterial consortium from overnight cultures at the log phase of growth - were transferred to $250 \mathrm{ml}$ conical flasks, each containing $50 \mathrm{ml}$ of sterile defined mineral salts medium (MSM), with the following composition (g/l): $1 \mathrm{~g}\left(\mathrm{NH}_{4}\right)_{2} \mathrm{SO}_{4}, 0.3 \mathrm{~g} \mathrm{~K}_{2} \mathrm{HPO}_{4}, 0.01 \mathrm{~g}$ $\mathrm{CaCl}_{2}, 0.2 \mathrm{~g} \mathrm{MgSO}_{4} .7 \mathrm{H}_{2} \mathrm{O}, 0.01 \mathrm{~g} \mathrm{FeSO}_{4}$, and $0.1 \mathrm{~g}$ yeast extract. The medium was supplemented with $1 \%$ crude oil and adjusted to $\mathrm{pH} 7$. Flasks were then incubated at $35^{\circ} \mathrm{C}$ and $120 \mathrm{rpm}$ in a shaker incubator for 15 days. The growth of bacteria on crude oil was monitored by measuring the optical density at $600 \mathrm{~nm}$ using a spectrophotometer. Total petroleum hydrocarbon (TPH) removal efficiency was calculated and the standard curve was constructed.

The strains were identified and characterized to the species level as Pseudomonas aeruginosa, Bacillus licheniformis, Bacillus shaericus, and Bacillus brevis according to Bergey's manual of systematic bacteriology with help from the Fermentation Biotechnology and Applied Microbiology Center (Ferm- BAM) at El Azhar University, Nasr city, Egypt [13]. Furthermore, the 16S rRNA gene of the most potent strain was amplified by PCR using the primers 16F27 and 16R1492 from the genomic DNA, and sequenced as described by Sambrook et al. [14]. DNA sequencing was performed by Macrogen Inc., Korea. The Blast Program was used to assess DNA similarities. The strain was identified as Pseudomonas aeruginosa KH6 and was submitted to GenBank under the accession number KM194714 (data not shown). 


\section{Optical Density Determination}

The culture broths were taken for growth determination photometrically at $600 \mathrm{~nm}$ using spectrophotometer (Pharmacia Biotech, Novaspec II).

\section{Determining Total Petroleum Hydrocarbons (TPH)}

The total petroleum hydrocarbon in the investigated samples was determined spectrophotometrically [15] at wavelength $420 \mathrm{~nm}$, at the Central Laboratory of the Faculty of Science, Alexandria University, Egypt (PERKINELMER, Lambda 4B, UV/VIS Spectrophotometer). A standard curve was prepared using known concentrations of crude oil that were used to estimate the amount of hydrocarbons in the samples. The removal efficiency (RE \%) of the crude oil was calculated according to the following equation:

\section{Removal efficiency $(\mathrm{RE} \%)=(\mathrm{TPH}$ Control - TPH Treated) / TPH Control) x 100}

...where TPH Control is the oil concentration of the control and TPH Treated is the oil concentration of the biodegraded sample. All the biodegradation experiments were carried out in duplicate with the live bacterial cultures and the controls. The oil removal efficiency was acquired as the average value.

\section{Gas Chromatography Mass Spectrometry}

\section{Extraction Procedure}

The standard operating procedure (SOP-0001) provides a precise and accurate method to quantitatively determine organic compounds in water. Aqueous samples were serially extracted with methyl dichloride using the separatory funnel technique and the extract was dried. The extract was concentrated and the solvent exchanged if required [16].

\section{Purification and Fractionation Procedure}

According to standard operating procedure (SOP9720), silica/alumina column chromatography was used to eliminate the interfering materials and allow quantitative recovery of the target compounds. Standard operation procedures were used to isolate the aliphatic and aromatics fractions from the extracted samples. The fractions containing the desired target compounds were collected and concentrated prior to analysis [17]. Aliphatic and aromatic hydrocarbon fractions were analyzed with a Thermo Scientific gas chromatograph equipped with a mass selective detector (GC-MS) using a $30 \mathrm{~m}$ x $0.32 \mathrm{~mm}$ and $0.25 \mu \mathrm{m}$ film thickness, at the Central Laboratory of the Institute of Graduate Studies and Research, Alexandria University.

\section{Immobilization of Bacterial Strains}

\section{Entrapment in Calcium Alginate}

Different bacterial strains were entrapped in $4 \%$ sodium alginate gel beads ( $4 \%$ sodium alginate solution was prepared by dissolving $1 \mathrm{~g}$ in $15 \mathrm{ml}$ distilled water and then autoclaving at $108^{\circ} \mathrm{C}$ for 10 minutes). $10 \mathrm{ml}$ of bacterial cultures obtained from nutrient broth media were added to the sterile alginate solutions to obtain $4 \%$ final concentration of the biocarrier [18].

\section{Entrapment in Agar Cubes}

The gel was prepared by dissolving $2 \mathrm{~g}$ agar in $60 \mathrm{ml}$ distilled water (2\%). $4 \mathrm{ml}$ of bacterial cultures were aseptically poured into a Petri-dish $(10 \mathrm{ml}$ for each). Gel cubes of the biocarrier of about $0.5 \mathrm{~cm}$ in length were transferred into $250 \mathrm{ml}$ Erlenmeyer flasks containing $50 \mathrm{ml}$ of the previously described medium [19].

\section{Adsorption on Solid Supports}

Four $\mathrm{ml}$ of bacterial cell suspensions of different bacterial strains were added to $250 \mathrm{ml}$ Erlenmeyer flasks containing $50 \mathrm{ml}$ of sterilized optimized mineral salt medium with $1 \%$ of crude oil, and one of the different carrier materials such as polyethylene $(5 \mathrm{~g})$ or molecular sieve $(7 \mathrm{~g})$, and biocarriers such as clay (10 g), sponge $(0.5 \mathrm{~g})$, and nut shell particles $(3 \mathrm{~g})$.

\section{Batch Cultures}

Batch cultures were performed using $250 \mathrm{ml}$ flasks inoculated with $4 \mathrm{ml}$ of free bacterial cultures, or inoculated with different biocarriers as $4 \mathrm{~g}$ of alginate beads or $2 \mathrm{~g}$ of agar cubes containing immobilized cells, or different solid supports adsorbing cells. A trickle flow column was also used for batch cultivation. The column was made of transparent cylindrical glass of $2.5 \mathrm{~cm}$ diameter and $25 \mathrm{~cm}$ height. The column was connected by a quick fit to a reservoir ( $250 \mathrm{ml}$ conical flask) and filled with adsorbent granules ( $0.5 \mathrm{~g}$ sponge or $5 \mathrm{~g}$ polyethylene) for adsorption, and $8 \%$ cell solution was used to inoculate the support. After adsorption of cells on the packed supportmatrix, approximately $150 \mathrm{ml}$ of the optimized mineral salt medium was recycled through the support by the aid of a peristaltic pump at a flow rate of about $120 \mathrm{ml} / \mathrm{h}$. The column was also aerated with a sterile air pump from the upper part of the column at a flow rate of about $0.211 / \mathrm{min}$ and incubated at $35^{\circ} \mathrm{C}$ for 15 days. MSM medium supplemented with $1 \%$ crude oil (as indicated above) was used for cultivation in flasks or column. Uninoculated flasks or column and flasks with sterile alginate beads, agar cubes, and sterile solid supports were used as negative controls in order to evaluate total hydrocarbon removal efficiency. All flasks were incubated at $35^{\circ} \mathrm{C}$ in a rotary shaker at $120 \mathrm{rpm}$ for 15 days. The samples were stored at $-20^{\circ} \mathrm{C}$ and processed together at the 
end of the experiment. All experiments were performed in duplicate.

\section{Simulation of Wastewater Bioremediation}

Different treatment strategies were applied using biostimulation, which includes oily wastewater treatment for unsterilized wastewater supplemented with such nutrients as $1 \mathrm{~g} / 1\left(\mathrm{NH}_{4}\right)_{2} \mathrm{SO}_{4}, 0.3 \mathrm{~g} / 1 \mathrm{~K}_{2} \mathrm{HPO}_{4}, 0.01 \mathrm{~g} / 1$ $\mathrm{CaCl}_{2}, 0.2 \mathrm{~g} / 1 \mathrm{MgSO}_{4} \cdot 7 \mathrm{H}_{2} \mathrm{O}, 0.01 \mathrm{~g} / \mathrm{Fe}_{2} \mathrm{SO}_{4}$, and $0.1 \mathrm{~g} / 1$ yeast extract in the absence of the tested strains. The bioaugmentaion technique includes oily wastewater treatment for sterilized wastewater in the presence of mixed bacterial cultures and without nutrient supplements. A combination of biostimulation and bioaugmentation techniques included wastewater with consortium bacterial cultures and with the above nutrients. A control sample was also included containing sterilized wastewater without nutrients and without strains [20].

\section{Results and Discussion}

\section{Effect of Immobilization on Biodegradation of Crude Oil by Bacterial Strains}

The gel cell beads (or cubes) and adsorbed cells on supports were used to inoculate $50 \mathrm{ml}$ of mineral salt medium supplemented with $1 \%$ crude oil. The results recorded in Fig. 1 show a comparison of oil removal efficiencies by either free or immobilized cells, which indicated that the highest TPH removal efficiencies were obtained from different bacterial strains adsorbed on sponge cubes and that ranged between $81.18 \%$ (which was obtained by $P$. aeruginosa KH6) and $70.03 \%$ (by $B$. sphaericus) - even higher than that of free cells. This is followed by entrapment by alginate beads by $P$. aeruginosa KH6, which was $79.83 \%$ and $78.11 \%$ for B. brevis, while entrapment in agar cubes followed adsorption on sponge cubes by giving $68.61 \%$ by $B$. licheniformis and

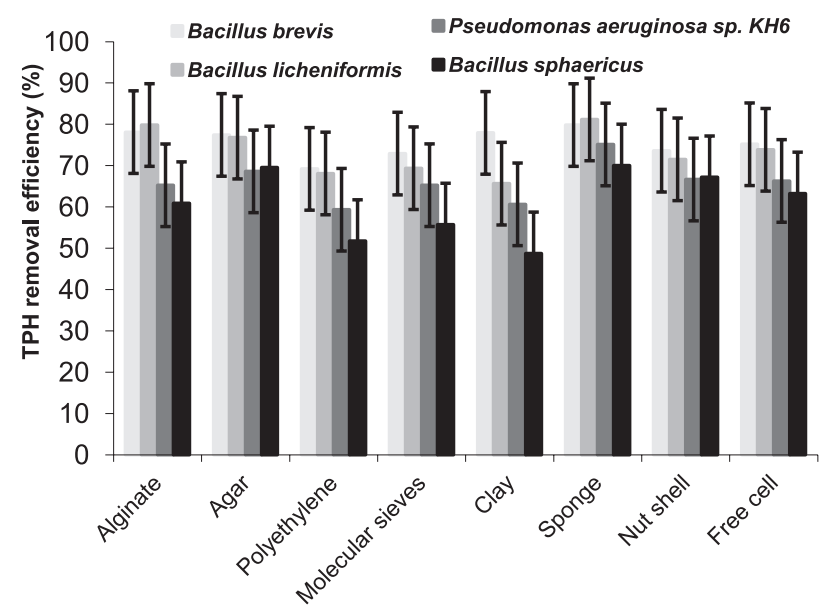

Fig. 1. Effect of immobilization on biodegradation of crude oil by bacterial strains.
$69.54 \%$ by B. sphaericus. However, other solid supports (polyethylene, molecular sieve, and clay) showed a decrease in TPH removal efficiencies. The lowest TPH removal efficiency (48.75\%) was reported by adsorbed cultures of B. sphaericus on clay.

The results revealed the possible biodegradation of crude oil by adsorbed or entrapped cells of the four bacterial strains as revealed by many investigations [9, 11, 21-26]. The oil-degrading ability of the immobilized bacterial consortium was compared by Nunal et al. [24] using cocopeat, rice hull powder, and sodium alginate capsules. They reported that immobilization of the oildegraders on the surface of cocopeat was higher compared to encapsulation in sodium alginate gel. Higher oil reduction by the cocopeat-immobilized cells is presumably due to the highly sustained microbial population attached to the surface of the biocarrier, providing a protective niche. The porous nature of cocopeat might allow for efficient substrate diffusion, a slow release of nutrients, and acceleration of oxygen transfer - thus providing a favorable niche for hydrocarbon utilization. While Lan et al. [22] studied the ability of Yarrowia lipolytica W29 immobilized in calcium alginate beads to degrade oil, the degradation efficiency of oil by immobilized cells was above $80 \%$. Immobilized cells had high thermostability compared to that of free cells. Storage stability and reusability tests revealed that the oil degradation ability of immobilized cells was stable after storage at $4^{\circ} \mathrm{C}$ for 30 days and being reused 12 times. Also, Shen et al. [26] discovered that cultures adsorbed on semi-coke followed by walnut shell and activated carbon showed higher biodegradation efficiency on petroleum hydrocarbons than free cultures; scanning electron microscope analysis suggested that the porosity of the carrier and the easy adherence of the microbial culture explain why.

The crucial role of immobilization is that it can offer protection from extreme $\mathrm{pH}$ and toxic compounds in contaminated systems. In this application, the immobilized bacteria acted as a bulking agent, facilitating the transfer of oxygen, nutrition, and metabolism products crucial for rapid hydrocarbon degradation and increased biological stability [21].

The scanning electron micrograph for free cells of $P$. aeruginosa sp. KH6 (Fig. 2), entrapped cells of B. brevis in alginate (Fig. 3), P. aeruginosa sp. KH6 adsorbed on molecular sieves (Fig. 4), B. sphaericus adsorbed on nut shell, (Figs 5 a and b), and B. licheniformis adsorbed on sponge cubs (Figs $6 \mathrm{a}$ and $\mathrm{b}$ ) showed good growth of free cells, cells entrapped in alginate beads, cells adsorbed on molecular sieves, nut shell particles, and sponge cubes, thus suggesting that the ability of microbial adaptation to the environment can be improved by immobilization [26].

\section{Biodegradation of Crude Oil by Batch Cultivation of Individual and Mixed Bacterial Consortium}

In a trial to investigate the effect of bacterial consortium on biodegradation efficiency, equal volumes (approximately equal densities) of culture broth of the 
four isolates were used to prepare a mixed bacterial consortium. The individual and mixed bacterial consortia from overnight culture at the log phase of growth were used to inoculate mineral salt medium with $1 \%$ crude oil. Fig. 7 indicates that the highest crude oil degradation was achieved by mixed culture showing $81.70 \%$ removal efficiency, followed by individual cultures that showed slightly lower removal efficiencies as B. brevis $(75.42 \%)$, P. aeruginosa KH6 (73.97\%), B. licheniformis (66.3\%), and B. sphaericus $(63.34 \%)$.

These results agree with other studies [26-29]. Sunita et al. [29] reported faster utilization of hydrocarbon by mixed cultures than the individual bacterial strain .The phenomenon was explained by Venosa and Zhu [27], who assumed that there is no single strain with the metabolic

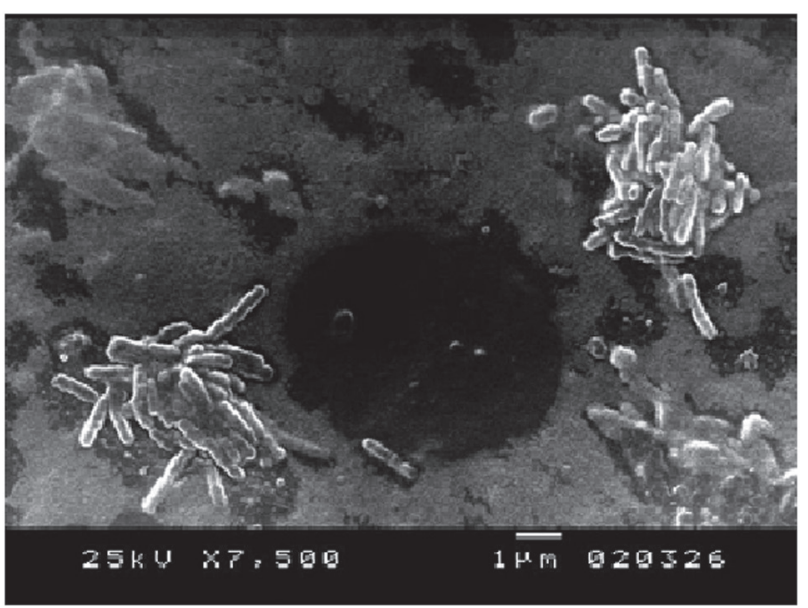

Fig. 2. Scanning electron micrograph for free cells of Pseudomonas aeruginosa sp. KH6.

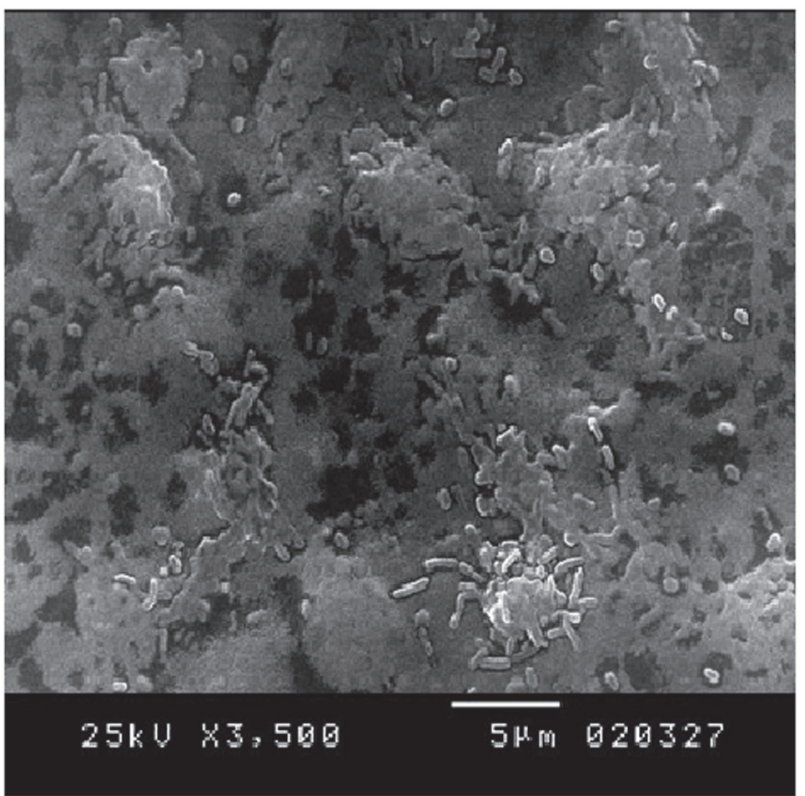

Fig. 3. Scanning electron micrograph of Bacillus brevis immobilized in alginate. capacity to degrade all components found within crude oil. In nature, biodegradation of a crude oil typically involves a succession of species within the consortia of microbes present. However, Pimda and Bunnag [30] studied the biodegradation of motor oil using single and mixed cultures of Nostoc hatei and Synechocystis aquatilis, and reported the highest degradation rate after 14 days using the single culture of $N$. hatei.

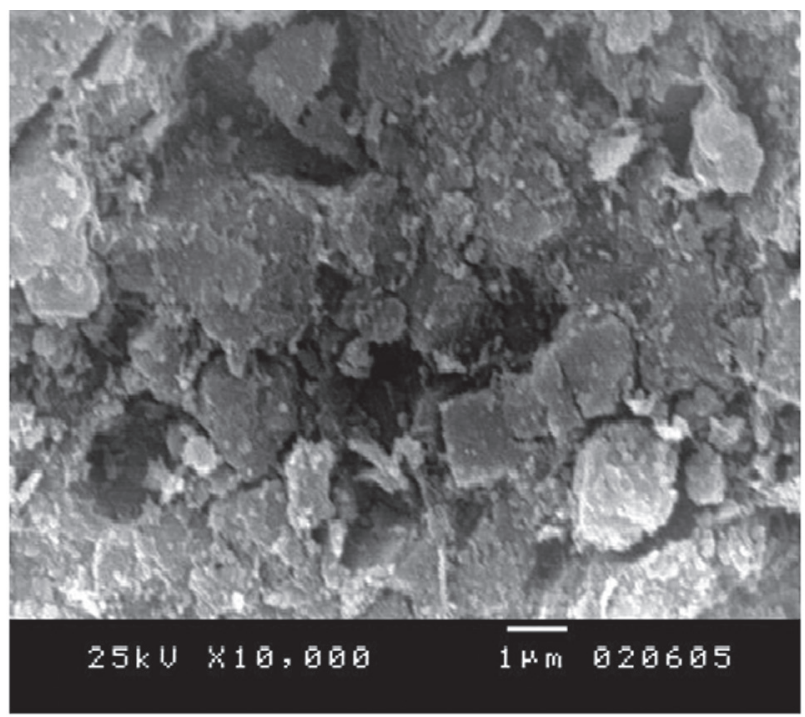

Fig. 4. Scanning electron micrograph of Pseudomonas aeruginosa sp. KH6 immobilized on a molecular sieve.

(a)

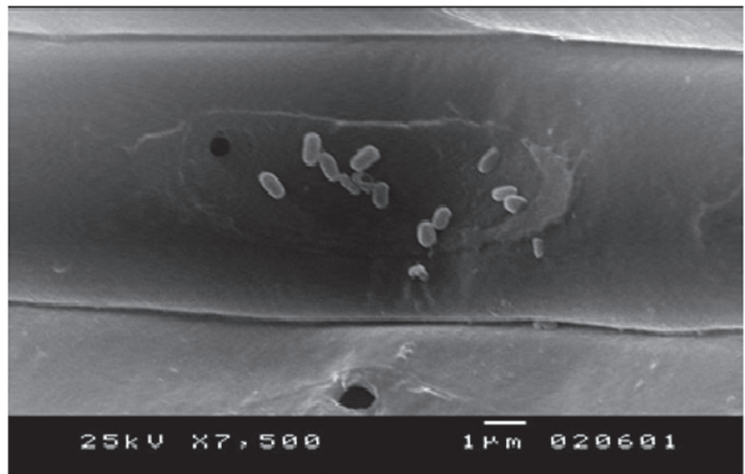

(b)

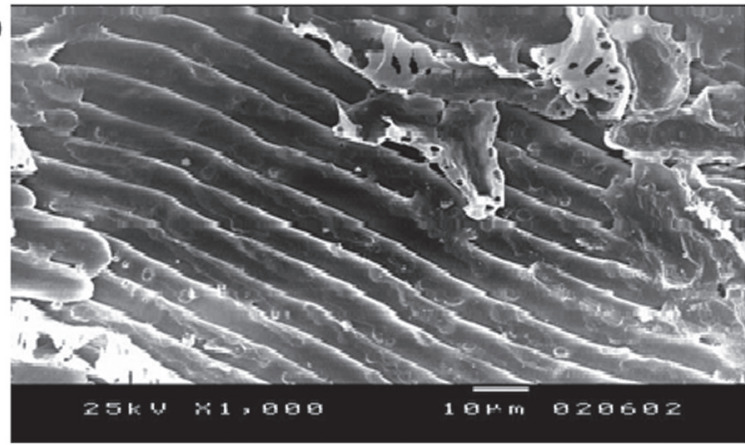

Fig. 5 a), b). Scanning electron micrographs of Bacillus sphaericus immobilized on a nutshell. 
(a)

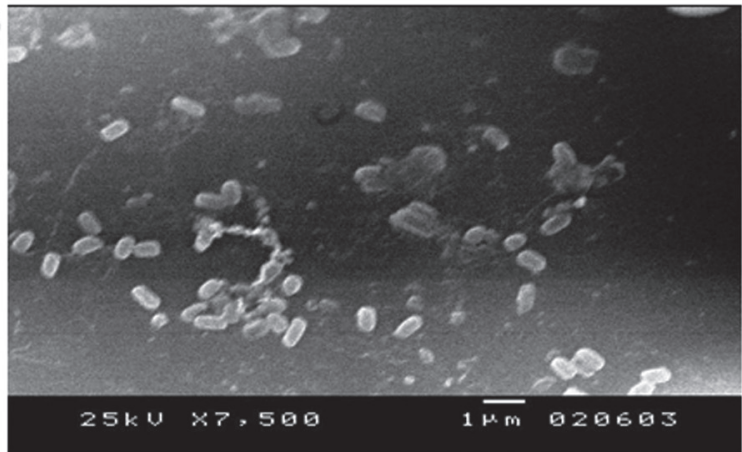

(b)

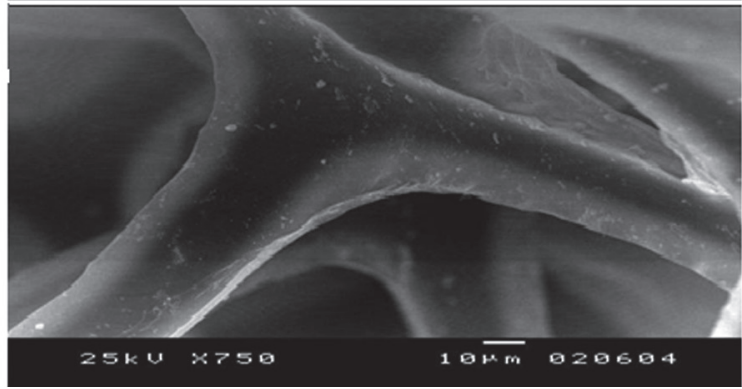

Fig. 6 a), b). Scanning electron micrographs of Bacillus licheniformis immobilized on a sponge.

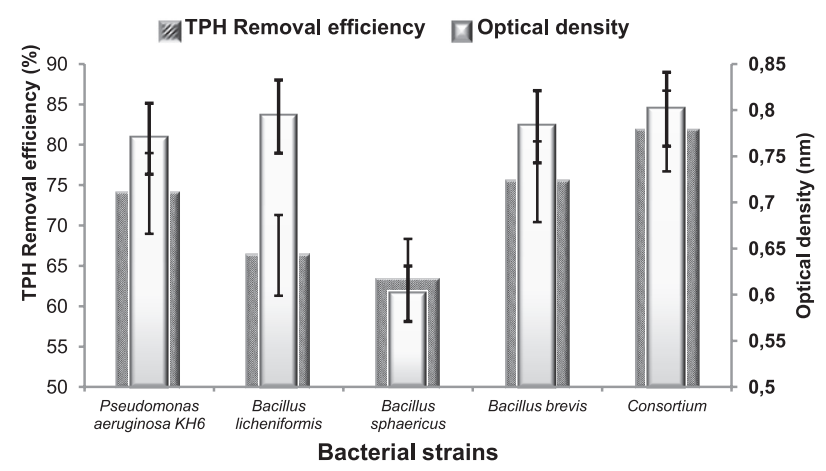

Fig. 7. TPH removal efficiency of crude oil by batch cultivation of individual and mixed bacterial consortium.

\section{Batch Cultivation of Adsorbed Individual and Mixed Cultures on Sponge in a Trickle Flow Bioreactor}

To test the possible degradation of crude oil in a bioreactor, a trickle-flow column was used for cultivation of individual and mixed cultures adsorbed on a biocarrier of sponge cubes, and used to inoculate $150 \mathrm{ml}$ of mineral salt-optimized medium supplemented with $1 \%$ crude oil. Fig. 8 clearly shows that there was an increase in removal efficiency within the bioreactor than that achieved within flasks, and the highest crude oil degradation was obtained by mixed culture giving $87.53 \%$ removal efficiency, followed by individual cultures that gave $82.97 \%$ for P. aeruginosa KH6, $81.5 \%$ for B. brevis, $77.3 \%$ for $B$. licheniformis, and $73.0 \%$ for $B$. sphaericus, respectively.

Removal of hazardous materials was extensively studied using bioreactors [31-34]. Chikere et al. [33] used

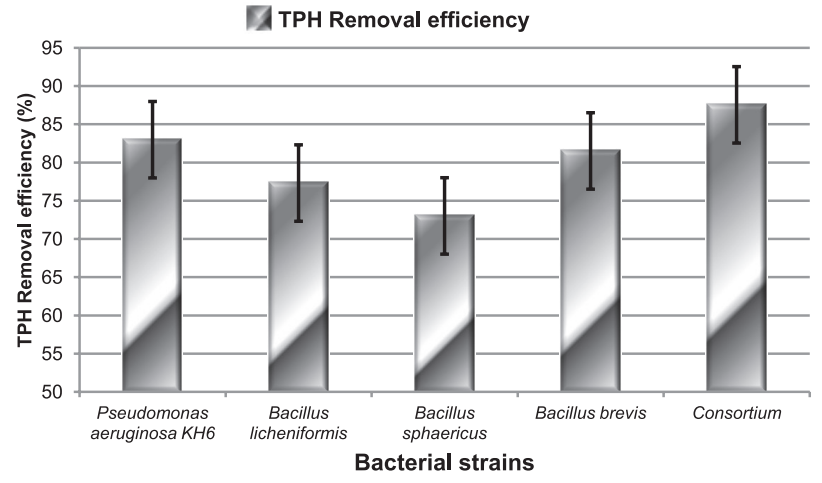

Fig. 8. TPH removal efficiency of crude oil by adsorbed individual and mixed cultures on sponge in a trickle flow bioreactor.

seven stirred tank bioreactors for the bioremediation of marine sediments impacted with petroleum hydrocarbons (crude oil and anthracene). Different nutrient regimens were formulated using organic and inorganic nutrient sources, namely NPK fertilizer, urea fertilizer, and poultry litter to enhance the biodegradation of the pollutants by the extant autochthonous marine hydrocarbon-degrading bacteria.

The increase in TPH removal efficiency in bioreactors was explained by the study that designed a new bioreactor system to increase the efficiency of biological treatment systems by allowing greater organic loads, minimizing production of sludge waste by-products, and increasing process stability and resistance to shock loading [31].

\section{Gas Chromatography-Mass Spectrometry}

Gas chromatography-mass spectrometry (GC-MS) analysis was carried out to evaluate the effect of the biodegradation process on the concentrations of the aliphatic and aromatic hydrocarbon fractions. The sample used for GC-MS analysis showing 87.53\% removal efficiency was obtained from cultivating a mixed culture adsorbed on sponge cubes packed in the bioreactor containing defined mineral salt medium supplemented with crude oil. Figs 9 a) and b) show the chromatographic profile of the aliphatic hydrocarbons extracted from the control and the mixed culture adsorbed on sponge. The results revealed a carbon number distribution from $\mathrm{C}_{13}$ to $\mathrm{C}_{32}$. Aliphatic hydrocarbons extracted from the sample inoculated with the adsorbed mixed culture indicated that petroleum hydrocarbon degradation was clear by the mixed culture. Fig. 9 b) showed a remarkable decrease in the concentrations of $n-\mathrm{C}_{13}-n-\mathrm{C}_{32}$, as well as a slight decrease in $\mathrm{C}_{17} /$ pristane and $\mathrm{C}_{18} /$ phytane ratios relative to those in control samples. Both $\mathrm{Pr}$ and $\mathrm{Ph}$ are the dominant saturated hydrocarbon components of the highly weathered crude oil. They are degraded only under sever weathering conditions as agreed upon by Wang et al. [35].

The concentrations of some identified aromatic hydrocarbons (flurene, phenanthrene, anthracene, pyrene, and chrysene) of the control and the mixed bacterial culture are illustrated in Fig. 10. The results indicate that 

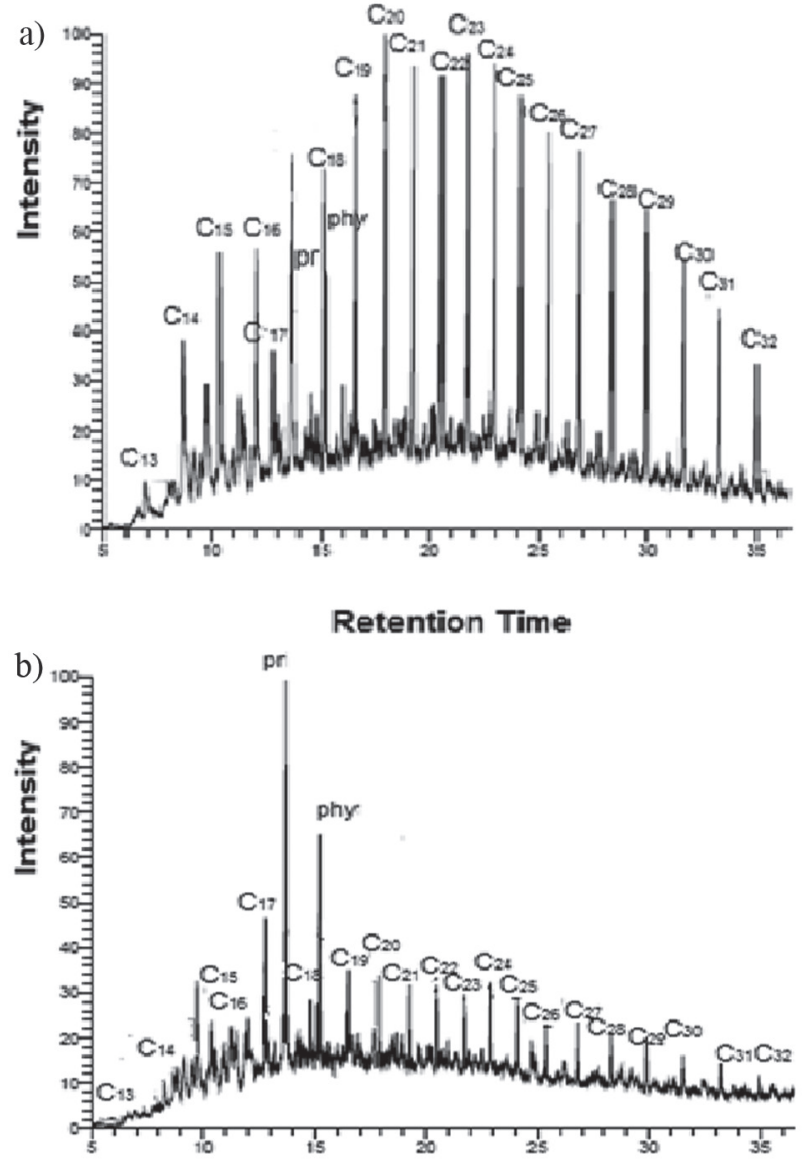

Retention time

Fig. 9a, b: Gas chromatogram of aliphatic hydrocarbon fraction of the control a) and mixed culture b) samples.

the degradation of the aromatic hydrocarbon fraction was enhanced by mixed culture and this is obviously illustrated by a remarkable decrease in the concentrations of aromatic hydrocarbon fractions, especially for flurene,

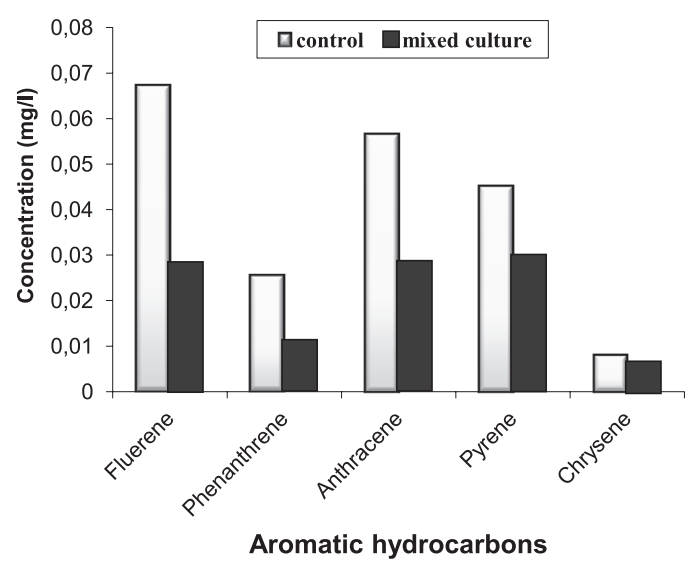

Fig. 10. Concentrations of aromatic compounds of crude oil in the control and mixed culture samples.

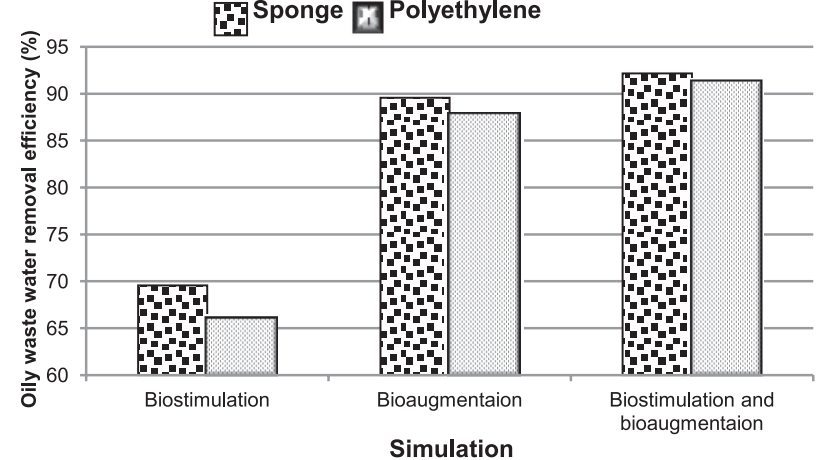

Fig. 11. Oily wastewater removal efficiency (\%) by simulation using adsorbed mixed cultures in a trickle flow column.

phenanthrene, anthracene, pyrene, and a slight decrease for chrysene than that in the control sample. Several studies have described the ability of mixed bacterial consortia to degrade $28-51 \%$ of saturates and $0-18 \%$ of aromatics present in crude oil, or up to $60 \%$ [36-38]. Compounds such as saturates, aromatics, and polar compounds present in different crude oil samples were degraded to different degrees by the same organisms [39].

The usefulness of the gas chromatographic fingerprinting technique as a veritable tool for oil spill source identification, evaluation of origin of oil, and biodegradation was illustrated by Oforka et al. [40].

\section{Simulation of Oily Wastewater Bioremediation}

It is important to find out the most suitable way for bioremediation of industrial oil-polluted wastewater. For biostimulation, the optimum concentration of nutrients (as described in Methods) was added to $150 \mathrm{ml}$ unsterilized oily wastewater in a bioreactor packed with sponge or polyethylene to stimulate indigenous microbial population. For bioaugmentation, the designed bacterial consortium adsorbed on sponge or polyethylene was used to inoculate $150 \mathrm{ml}$ of sterilized oily wastewater without nutrients to determine the efficiency of bacterial consortium for oily wastewater degradation. A combination of biostimulation and bioaugmentation techniques was applied on the oily wastewater to investigate the suppressive effects of the two techniques. The results in Fig. 11 indicate that the highest oily wastewater removal efficiencies were through biostimulation and bioaugmentation together, in a bioreactor packed with sponge or polyethylene $(92.17 \%$ and $91.30 \%$, respectively), followed by bioaugmentation $(89.56 \%$ and $87.82 \%)$ and biostimulation $(69.56 \%$ and $66.08 \%$ ).

These results agreed with studies that revealed that a combination of both biostimulation and bioaugmentation techniques is the optimum strategy for bioremediation $[20,41-42]$. The highest pyrene reduction in percentage $(84.29 \%)$ was obtained through the combined bioaugmentation-biostimulation process, followed by 
bioaugmentation $(57.86 \%)$, biostimulation $(50 \%)$, and control (37\%) processes [41]. However, other studies revealed that the bioaugmentation strategy performed better in the reduction of total petroleum hydrocarbon levels than biostimualtion [43], while biostimulation and bioaugmentation achieved $60 \%$ and $34 \%$ oil hydrocarbon degradation, respectively [44].

\section{Conclusions}

Four crude oil-degrading bacteria were isolated from industrial oil-polluted wastewater from API separators of the Alexandria Petroleum Company. The strains were identified as $P$. aeruginosa, $B$. licheniformis, B. shaericus, and $B$. brevis. The most potent strain was identified using a method based on 16S rRNA gene sequencing. The strains have great potential to grow free or be immobilized in or on inexpensive natural materials, and that immobilization can enhance the bioremediation of oil-contaminated wastewater. Comparing individual cultures with mixed ones showed an enhancement in removal efficiency when using immobilized mixed cultures within a bioreactor by 1.08-fold than immobilized individual cultures within Erlenmeyer flasks. Conducting simulation experiments in batch bioreactors for treatment of oily wastewaters showed an increase in biodegradation by combining biostimulation and bioaugmentation.

\section{References}

1. BACHMANN R.T., JOHNSON A.C., EDYVEAN R.G. Biotechnology in the petroleum industry: An overview. Int. Biodeterior. Biodegrad. 85, 225-237, 2014.

2. NIKOLOPOULOU M., KALOGERAKIS N. Biostimulation strategies for enhanced bioremediation of marine oil spills including chronic pollution. In: Timmis $\mathrm{KN}$, editor. Handbook of hydrocarbon and lipid microbiology. SpringerVerlag; Berlin. 2521, 2010.

3. DELLA TORRE C., TORNAMBE A., CAPPELLO S., et al. Modulation of CYP1A and genotoxic effects in European seabass Dicentrarchus labrax exposed to weathered oil: A mesocosm study. Mar. Environ. Res.76, 48, 2012.

4. CAPPELLO S., SANTISI S., CALOGERO R., HASSANSHAHIANM., YAKIMOVM. M. Characterization of Oil-Degrading Bacteria Isolated from Bilge Water. Wat. Air Soil Pollut. 223, 3219, 2012.

5. PATEL V., SHAH K. Petroleum Hydrocarbon pollution and its Biodegradation. Int. J. Chem. Technol. Appl. 2, 63, 2012.

6. ZAHED M.A., AZIZ H.A., ISA M.H., MOHAJERI L. Effect of initial oil concentration and dispersant on crude oil biodegradation in contaminated sea water. Bull. Environ. Contam. Toxicol. 84, 438, 2010.

7. JOUTEY N.T., BAHAFID W., SAYEL H., EL GHACHTOULI N. Biodegradation: Involved Microorganisms and Genetically Engineered Microorganisms. Chapter 11; http:// dx.doi.org/10.5772/56194, 2013

8. SINHAL S., CHATTOPADHYAY P., PAN I., CHATTERJEE S., CHANDAL P., DAS K., SUKANTA K., BANDYOPADHYAY S.D. Microbial transformation of xenobiotics for environmental bioremediation. Afri. J.
Biotech. 8, (22), 6016, 2009

9. FEIJOO-SIOTA L.F., ROSA-DOS-SANTOS, DE MIGUEL T., VILLA T.G. Biodegradation of Naphthalene by Pseudomonas stutzeri in Marine Environments: Testing Cells Entrapment in Calcium Alginate for Use in Water Detoxification. Biorem. J. 12 (4), 185, 2008.

10. DAS M., ADHOLEYA A. Potential Uses of Immobilized Bacteria, Fungi, Algae, and Their Aggregates for Treatment of Organic and Inorganic Pollutants in Wastewater. ACS Symposium Series, Chapter 15, 1206, 319, 2015.

11. BAO M., CHEN Q., GONG Y., LI Y., WANG H., JIANG G. Removal efficiency of heavy oil by free and immobilized microorganisms on laboratory-scale. Can .J. Chem. Eng. 91, $1,2013$.

12. RIZZO A.C.D.L., DOS SANTOS R.D.M., DOS SANTOS R.L.C., SORIANO A.U., CUNHA C.D.D., ROSADO A.S., SOBRALAL.G.D.S., LEITE S.G.F. Petroleum-contaminated soil remediation in a new solid phase bioreactor. J. Chem. Technol. Biotechnol. 85, 1260, 2010.

13. HOLT J.G., KREIG N.R., SNEATH P.H.A., STANELY J.T., WILLIAMS S.T. Bergey's Manual of Determinative Bacteriology. Williams and Wilkins Publishers, Maryland, 753, 1994

14. SAMBROOK J., FRITSCH E. F., MANIATIS T. Molecular cloning. A Laboratory Manual. Cold spring Harbor, NY: Cold Spring Harbor Laboratory Press, 545, 1989.

15. ODU C.T., NWOBOSHI L.C., ESURUSO O.F. Environmental study of the Nigerian Agip oil company operation areas. In proceedings of the International Seminar on the Petroleum Industry and the Nigeria Environment held at Kaduna, Nigeria, 274, 1985.

16. GERG, standard operating procedure, Extraction of water samples for analysis of organic compounds using the separatory funnel technique. (9218) Revision 1, 3, 2005.

17. GERG, standard operating procedure, Silica /Alumina column chromatography for the purification of extracts to the analysis of aliphatic and aromatic hydrocarbon. (9720) Revision 1, 1, 2005.

18. EIKMEIER H., WESTTMEIER F., REHM H. J. Morphological devolpment of Aspergillus niger immobilized in Ca-alginate and K-carrageenan. Appl. Microbiol. Biotechnol. 19, 53, 1984.

19. CHAPATWALA K. D., BABU G. R. V., WOLFRAM J. H. Screening of encapsulated microbial cells for the degradation of inorganic cyanides. J. Ind. Microbiol. Biotechnol. 11, 69, 1993.

20. BEREKAA M.M., MOSTAFA A., GHANEM A.A. Bioremediation of crude oil contaminated soil by Pseudomonas aeruginosa strain-O, and Micrococcus Varians strain-X with different approaches. Biotechnol. 7, $1,2013$.

21. PARK H.G., KIM T.W., CHAE M.Y., YOO I.K. "Activated Carbon-Containing Alginate Adsorbent for the Simultaneous Removal of Heavy Metals and Toxic Organics," Process Biochem. 42, 1371, 2007.

22. LAN W.U., GANG G.E., JINBAO W.A.N. Biodegradation of oil wastewater by free and immobilized Yarrowia lipolytica W29, J. Environ. Sci. 21, 237, 2009.

23. LIANG Y., ZHANG X., DAI D., et al. Porous biocarrier enhanced biodegradation of crude oil contaminated soil. Int. Biodeter. Biodeg. 63, 80, 2009.

24. NUNAL S.N., SANTANDER-DE LEON S.M., BACOLOD E., KOYAMA J., UNO S., HIDAKAM., et al. Bioremediation of heavily oil-polluted seawater by a bacterial consortium immobilized in cocopeat and rice hull powder. Biocontrol Sci. 19 (1), 11, 2014. 
25. BAYAT Z., HASSANSHAHIAN M., CAPPELLO S. Immobilization of Microbes for Bioremediation of Crude Oil Polluted Environments: A Mini Review. Open Microbiol. J. 9, 48, 2015.

26. SHEN T., YONGRUI P., BAO M., XU N., LI Y., LU J. Biodegradation of different petroleum hydrocarbons by free and immobilized microbial consortia. Environ. Sci.: Processes Impacts 17, 2022, 2015.

27. VENOSA A.D., ZHU X. Biodegradation of Crude Oil Contaminating Marine Shorelines and Freshwater Wetlands. Spill. Sci. Technol. Bull. 8 (2), 163-178, 2003.

28. MORAIS E. B., TAUK-TORNISIELO S. M. Biodegradation of Oil Refinery Residues Using Mixed-Culture of Microorganisms Isolated from a Landfarming. Braz. Arch. Biol. Technol. 52 (6), 1571, 2009.

29. SUNITA J.V., VIVEK N.U. Comparative Studies on Bacterial Consortia for Hydrocarbon Degradation. International Journal of Innovative Research in Science. Engineering and Technology 2, 5378, 2013.

30. PIMDA W., BUNNAG S. Biodegradation of used motor oil by single and mixed cultures of cyanobacteria. Afr. J. Biotechnol. 11, 9074, 2012.

31. JOU C., HUANG G. A pilot study for oil refinery wastewater treatment using a fixed film bioreactor. Adv. Environ. Res. 7, 463, 2003.

32. ZAHED M.A., AZIZ H.A., ISA M.H., MOHAJERI L., MOHAJERI S., KUTTY S.R. Kinetic modeling and half life study on bioremediation of crude oil dispersed by Corexit 9500. J. Hazard. Mater. 185, 1027, 2011.

33. CHIKERE C.B., CHIKERE B.O., OKPOKWASILI G.C. Bioreactor-based bioremediation of hydrocarbon-polluted Niger Delta marine sediment, Nigeria. 3 Biotech. 2, 53, 2012.

34. ALAMI N.H., SHORAYA U.M., FATIMAH, NIMATUZAHROH. The Influence of Microbial Consortium in Bioremediation Process Using Bioreactor. IPTEK J. Sci. 1 (1), 1-4, 2014

35. WANG Z., FINGAS M., OWENS E.H., SIGOUIN L.,
BROWN C. E. Long-term fate and persistence of the spilled Metula oil in a marine salt marsh environment-Degradation of petroleum biomarkers. J. Chromatogr. 926, 275, 2001.

36. CHHATRE S., PUROHIT H.J., SHANKER R., KHANNA P. Bacterial consortia for crude oil spill remediation. Water Sci. Technol. 34, 187, 1996.

37. SUGIURA K., ISHIHARA M., SHIMAUCHI T., HARAYAMA S. Physicochemical properties and biodegradability of crude oil. Environ. Sci. Technol. 31, 45, 1997.

38. VASUDEVAN N., RAJARAM P. Bioremediation of oil sludge contaminated soil. Environ. Int. 26, 409, 2001.

39. TZARKOVA E.K., GROUDEVA V.I. Bioremediation of petroleum - polluted soils by adsorptive immobilized Cornyebacterium sp. RB-96. Biotechnol. Biotechnol. Equip. 14, 72, 2000.

40. OFORKA N.C., OSUJI LEO C., ONOJAKE M.C. Petroleum hydrocarbon fingerprinting of crude oils from umutu/bomu oil field in Niger Delta, Nigeria. Arch. Appl. Sci. Res. 4 (1), 246-253, 2012

41. GHALY A.E., YUSRAN A., DAVE D. Effects of Biostimulation and Bioaugmentation on The Degradation of Pyrene in Soil. J. Bioremed. Biodeg. S5: 001. doi:10.4172/2155-6199.S5-001, 2013.

42. DARMAYATI Y., HARPASIS S., SANUSI H.S., PRARTONO T., SANTOSA D.A., NUCHSIN R. The Effect of Biostimulation and Biostimulation-Bioaugmentation on Biodegradation of Oil-Pollution on Sandy Beaches Using Mesocosms. Inter. J. Mar. Sci. 5 (27), 1, 2015.

43. NWADINIGWE A.O., ONYEIDU E.G. Bioremediation of crude oil polluted soil using bacteria and poultry manure monitored through soybean productivity. Pol. J. Environ. Stud. 21, 171, 2012.

44. WU M., DICK W.A., LI W., WANG X., YANG Q., WANG T., et al. Bioaugmentation and biostimulation of hydrocarbon degradation and the microbial community in a petroleumcontaminated soil. Inter. Biodeter. Biodeg. 107, 1, 2016. 